\title{
Phenotypic and Genotypic Characterization of Paratyphoid Salmonellae isolated from Poultry in Delta Area- Egypt
}

\author{
Mohamed A. Lebdah ${ }^{1}$, Amal A.M. Eid ${ }^{1}$, Soad A. Nasef ${ }^{2}$ and Enas M. Hamad ${ }^{3 *}$ \\ ${ }^{1}$ Avian and Rabbit Medicine Department, Faculty of Veterinary Medicine, Zagazig University, \\ 44511, Egypt \\ ${ }^{2}$ Reference Laboratory for Veterinary Quality Control on Poultry Production, Animal Health \\ Research Institute, Dokki, Giza, Egypt \\ ${ }^{3}$ Animal Health Research Institute, Mansoura Provincial Lab, Egypt \\ Article History: Received: 8/5/2017 Received in revised form: 25/8/2017 Accepted: 8/9/2017
}

\begin{abstract}
The present work aimed to isolate and characterize Salmonellae from chickens, ducks, quails and turkeys in five Egyptian Governorates. Polymerase chain reaction (PCR) was used for the detection of common virulence genes. A total of 265 flock samples (150 chickens, 60 ducks, 30 quails and 25 turkeys) were collected from Dakahlia, Kafrelsheik, Damietta, Sharkia and Gharbia Governorates. Birds were subjected to either clinical and/or post-mortem examination, in adittion to isolation and identification of salmonellae from internal organs including liver, lung, spleen, caecum and unabsorbed yolk sac. Biochmeical and serological identification of the isolates was done. Twenty eight birds (10.6\%) were found positive for Salmonella isolation. The number and percentage of positive chickens, ducks, quails and turkeys were 16 (10.7\%), 7 (11.7\%), 3 (10\%) and 2 (8\%), respectively. Salmonella Typhimurium, S. Enteritidis, S. Kentucky, $S$. Paratyphi A, $S$. Molade, $S$. Heidelberg, $S$. Infantis and $S$. Apeyeme were isolated from chickens. While $S$. Enteritidis, $S$. Typhimurium, $S$. Paratyphi A, $S$. Kentucky, $S$. Inganda and $S$. Bargny were isolated from ducks. While, $S$. Virchow, $S$. Tamale and $S$. Typhimurium were isolated from Quails and $S$. Wingrove, finally, $S$. Kentucky were isolated from turkeys. Molecular characterization of common virulence genes Salmonella outer proteins (sopB), Plasmid encoded virulence gene $(s p \nu \mathrm{C})$, salmonella enterotoxin $(s t n)$ and bacterial colonization factor $(b c f C)$ showed the presence of stn and $b c f \mathrm{C}$ genes in all isolates, while, sopB and $S p v$ genes were present in $64.3 \%$ and $10.7 \%$, respectively. It is concluded that salmonellae with common virulence genes were widely spread among domestic birds in Delta areas, Egypt, resulting in economic and public health problems which require the application of strictly biosecurity measures in poultry rearing.
\end{abstract}

Keywords: Salmonella spp., Poultry, Delta, Virulence Genes

\section{Introduction}

Paratyphoid (PT) infection is an infectious disease of all domestic and wild birds. More than 2400 serotypes of salmonellae were recognized, and they can infect humans and different animals [1]. Paratyphoid infection is bacterial disease causing high economic losses among avian species. Paratyphoid salmonellae are Gram-negative; non-spore forming, non capsulating and motile by means of peritrichous flagellae [2]. The clinical findings of paratyphoid infection in all species of young birds are similar and include a progressive state of somnolence manifested by a tendency to keep head downward, close eyes with droopy wings, ruffled feathers, marked anorexia, increased water consumption, profuse watery diarrhea with pasting of the vent and a tendency of birds to huddle together near to the source of heat [3-5]. The dead birds in acute state show septicemia, while, those dying later show necrotic foci in the liver and/or heart, enlargement of gall bladder and unabsorbed yolk sac [6]. However, in severe outbreaks of PT infection in newly hatched birds, rapidly developing septicemia can cause a high rate of mortality with few or no apparent lesions. When the course of the disease is longer, severe enteritis is often accompanied by focal necrotic lesions in the mucosa of the small intestine. Cheesy cecal cores are often observed, spleens and livers are commonly swollen and congested with hemorrhagic streaks or necrotic foci, while, kidneys may sometimes be enlarged and 
congested [7]. Fibrinopurulent perihepatitis and pericarditis have been reported on numerous occasions, In addition, unabsorbed, coagulated yolk sac and other lesions occasionally are observed including hypopyon, panophthalmitis, purulent arthritis, serous typhilitis, air sacculitis and omphalitis [7].

The gold standard method for Salmonella detection is bacteriological culture, while, serotyping can also be used [8]. $S$. Enteritidis and $S$. Typhimurium are the most common serotypes isolated from poultry [9]. Differences in virulence among Salmonella serovars and in the course of Salmonella infections in various host species have been attributed to the variable acquisition and evolvement of virulence genes [10]. Salmonella species contain upwards of sixty virulence genes and have three antigenic $(\mathrm{H}, \mathrm{O}$, and $\mathrm{Vi})$ determinants [11].

The fimbrial gene $(b c f C)$ is located on a fimbrial structure and has a role in cell invasion [12]. Moreover, Salmonella outer proteins (Sop) has a role in the invasion of the bacteria through deformation of membranes and rearrangement of the host cells' cytoskeleton $[13,14] . S p v$ is related to survival and growth of the bacterium in host cells [15]. The salmonella enterotoxin (stn) gene encodes Stn protein, causing gastroenteritis with symptoms that include nausea, vomiting, abdominal pain, fever, and diarrhea [16]. The present study aimed to isolate salmonellae from birds in Delta area of Egypt and to determine the occurrence of PT in different poultry species. Moreover, detection of common virulence genes among isolated salmonellae was carried outusing PCR.

\section{Material and Methods}

\section{Sample collection}

A total of 265 flock samples of diseased and freshly dead chickens, ducks, quails and turkeys were collected from Dakahlia, Damietta, Gharbia, Kafrelsheik and Sharkia Governorates. Birds were subjected to either clinical and/or post-mortem examination for the isolation and identification of paratyphoid salmonellae from internal organs including liver, lung, spleen, caecum and unabsorbed yolk sac. The internal organs of 150 chickens, 60 ducks, 30 quails, 25 turkeys were collected under aseptic condition as possible to prevent cross contamination in ice box and were then transferred to the laboratory.

\section{Isolation of Salmonella species}

It was done according to ISO 6579 [17]. The tested sample was initially inoculated into a non-inhibitory liquid medium to favor the repair and growth of stressed or sublethallyinjured salmonellae arising from exposure to heat, freezing, desiccation, high osmotic pressure or wide temperature fluctuations.

Samples were weighed and suspended in Buffered Peptone water as 1:10 dilution and then incubated at $37^{\circ} \mathrm{C} \pm 1^{\circ} \mathrm{C}$ for $18 \pm 2 \mathrm{~h}$. From the pre-enrichment culture, $0.1 \mathrm{~mL}$ of the broth was transferred to a tube containing $10 \mathrm{~mL}$ of the Rappaport Vassiliadis broth and then incubated at $41.5^{\circ} \mathrm{C} \pm 1^{\circ} \mathrm{C}$ for $24 \pm 2 \mathrm{~h}$. From the enrichment culture, $10 \mu \mathrm{L}$ were inoculated onto the surface of Xylose Lysine Deoxycholate (XLD), Hektoen Enteric (HE) and MacConkey's plates, separately, then incubated at $37^{\circ} \mathrm{C} \pm 1^{\circ} \mathrm{C}$ for $24 \pm 2 \mathrm{~h}$. The plates were then checked for the growth of typical Salmonella colonies.

\section{Biochemical identification}

Hydrolysis of urea, $\mathrm{H}_{2} \mathrm{~S}$ production, TSI and Simmon's Citrate agar were done according to ISO 6579 [17]. Isolated strains were inoculated on to Christensen's urea agar slant and incubated at $37^{\circ} \mathrm{C} \pm 1^{\circ} \mathrm{C}$, then examined after four hours. If there was no change it was left for $24 \mathrm{~h}$ at $37^{\circ} \mathrm{C} \pm 1^{\circ} \mathrm{C}$. A Simmon's citrate agar slopes were inoculated as a single streak on the surface with the tested isolates and incubated at $37^{\circ} \mathrm{C}$ for $48 \mathrm{~h}$.

\section{Serological typing of paratyphoid salmonellae}

The isolates that were identified biochemically as Salmonella were subjected to serological identification according to Kauffman-White Scheme [18] for determination of somatic $(\mathrm{O})$ and flagellar $(\mathrm{H})$ antigens [19].

\section{Molecular identification of virulence genes}

All the isolates were examined by PCR for the presence of four virulence associated genes [20]. The genes under investigation were Salmonella outer protein B (sopB), Salmonella plasmid virulence $(s p v C)$ Salmonella enterotoxin encoding gene (stn) and bacterial colonization factor encoding gene $(b c f C)$. The primers sequences' and PCR product sizes are showen in (Table 1) [12,21]. 
Table 1: Sequences of the used oligonucleotide primers for identification of virulence genes among Salmonellae in poultry

\begin{tabular}{|c|c|c|c|}
\hline Genes & $\begin{array}{l}\text { Specificity/ } \\
\text { location }\end{array}$ & $\begin{array}{l}\text { Sequence of nucleotides } \\
\left(5^{\prime}-3^{\prime}\right)\end{array}$ & $\begin{array}{c}\text { Amplified } \\
\text { product (bp) }\end{array}$ \\
\hline \multirow{2}{*}{ Stn } & \multirow{2}{*}{$\begin{array}{l}\text { Enterotoxin/ } \\
\text { chromosomal }\end{array}$} & F- TTGTGTCGCTATCACTGGCAACC & \multirow{2}{*}{617} \\
\hline & & R-ATTCGTAACCCGCTCTCGTCC & \\
\hline \multirow{2}{*}{$\operatorname{sop} \mathbf{B}$} & \multirow{2}{*}{$\begin{array}{l}\text { Effector protein/ } \\
\text { SPI-5 }\end{array}$} & F-TCAGAAGTCGTCTAACCACTC & \multirow{2}{*}{517} \\
\hline & & R-TACCGTCCTCATGCACACTC & \\
\hline \multirow{2}{*}{$b c f C$} & \multirow{2}{*}{$\begin{array}{l}\text { Fimbrial usher } \\
\text { protein/ chromosome }\end{array}$} & F-ACCAGAGACATTGCCTTCC & \multirow{2}{*}{467} \\
\hline & & R-TTCTGCTCGCCGCTATTCG & \\
\hline \multirow[b]{2}{*}{$\operatorname{spv} \mathrm{C}$} & \multirow{2}{*}{$\begin{array}{l}\text { Plasmid encoded } \\
\text { virulence gene/ } \\
\text { plasmid }\end{array}$} & F-ACCAGAGACATTGCCTTCC & \multirow[b]{2}{*}{467} \\
\hline & & R-TTCTGATCGCCGCTATTCG & \\
\hline
\end{tabular}

\section{Results}

The clinical signs of the examined birds were retarded growth, depression, lameness, ruffled feathers, chicks huddling together, respiratory troubles, whitish watery diarrhea and accumulation of faecal matter around the vent (Figure 1: A, B). The postmortem examination of both freshly dead and sacrificed birds revealed gross lesion in the form of septicemia, bronze discolouration enlarged liver with necrotic foci, splenomegaly with necrotic foci, pericarditis, enlarged heart, peritonitis, congested kidneys, inflammation of intestine and caecum and unabsorbed yolk sac in young birds (Figure 1: C,D,E,F,G,H).
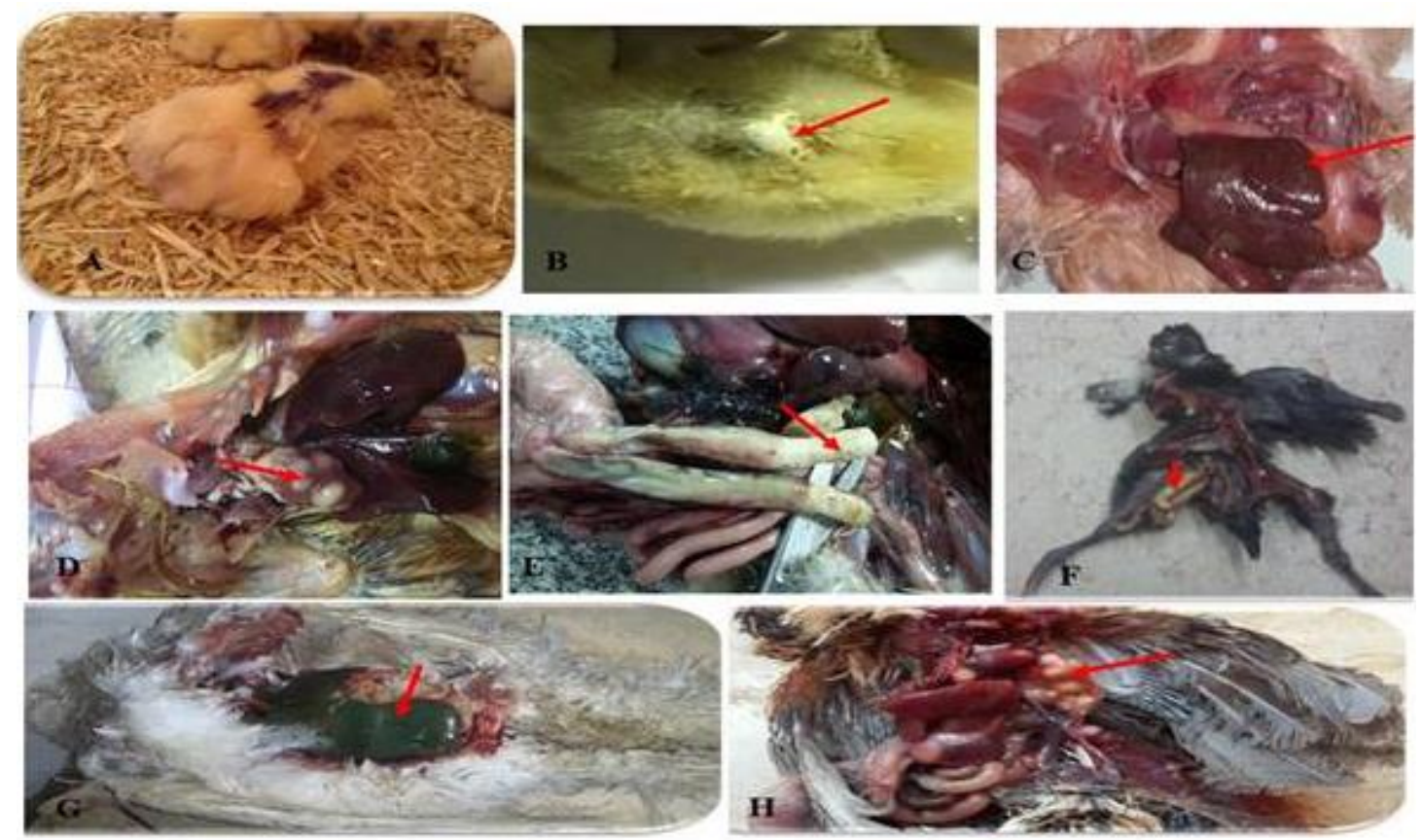

Figure 1: Signs and PM lesions of examined birds. A: Three days-old chick was sleepy with droopy wings. B: Diseased birds with pasty vent and whitish diarrhea. C: Twelve days-old Saso chicken died showing necrotic foci in the congested liver. D: 16 days-old chick showing several nodules on the heart and congested liver. E: 30 days-old chick showing Cecal cores,enteritis and septicemia. F: Ten days-old turkey with septicemia and cecal cores. G: Twenty days-old duckling died showing bronzy liver. H: Twenty five days-old quail died showing septicemia and nodules in the lungs and the heart. 
Out of 265 flock samples (150 chickens, 60 ducks, 30 quails and 25 turkeys), twenty eight birds $(10.6 \%)$ were positive for Salmonella isolation. The number and percentage of positive chickens, ducks, quails and turkeys were 16 (10.7\%), 7 (11.7\%), 3 (10\%) and 2 $(8 \%)$, respectively (Table 2). Salmonella isolates were serotyped using poly and monovalent "O" and" $\mathrm{O}$ " antisera and the results revealed that 16 strains isolated from chickens from different Governorates comporised of $4(25 \%) S$. Typhyimurium, 3 (18.8\%) S. Enteritidis, 3 (18.8\%) S. Kentucky, $2(12.5 \%)$ S. Paratyphi A, 1 (6.25\%) S. Molade, 1 (6.25\%) $S$. Heidelberg, 1 (6.25\%) $S$. Infantis and $1(6.25 \%) S$. Apeyene. Results of serotyping of 7 different salmonella strains from ducks showed 6 different serogroups identified as $S$. Entertidis (28.6\%), $S$. Typhimurium (14.3\%), S. Pararyphi A (14.3\%), S. Kentucky (14.3\%), S. Inganda $(14.3 \%)$ and $S$. Bargny (14.3\%). Serotyping of 3 different salmonellae from quails showed that 3 different serogroups were identified as $S$. Virchow (33.3\%), $S$. Tamale (33.3\%) and $S$. Typhimurium $(33.3 \%)$. While, serotyping of 2 different salmonellae from turkeys showed 2 different serogroups identified as $S$. wingrove $(50 \%)$ and $S$. Kentucky (50\%).

Molecular characterization using PCR revealed $b c f \mathrm{C}$ and sth genes in $100 \%$ of Salmonella isolates while, sopB gene was detected in $18(64.3 \%)$ isolates and $s p v \mathrm{C}$ gene was detected in 3 isolates $(10.7 \%$ ) (Table 3 and Figure 2).

Table 2: The isolation rates of Salmonella serotypes from poultry flocks

\begin{tabular}{|c|c|c|c|c|c|c|c|}
\hline \multirow{3}{*}{$\begin{array}{l}\text { Types of } \\
\text { flocks }\end{array}$} & \multirow{3}{*}{$\begin{array}{c}\text { No of } \\
\text { examined } \\
\text { samples }\end{array}$} & \multicolumn{4}{|c|}{ Prevalence of Salmonella isolation } & \multicolumn{2}{|c|}{ Isolated serotypes } \\
\hline & & \multicolumn{2}{|c|}{ Positive samples } & \multicolumn{2}{|c|}{ Negative samples } & \multirow[b]{2}{*}{ serotype } & \multirow[b]{2}{*}{ Number $(\%)$} \\
\hline & & No & $\%$ & No & $\%$ & & \\
\hline \multirow{8}{*}{ Chickens } & \multirow{8}{*}{150} & \multirow{8}{*}{16} & \multirow{8}{*}{10.7} & \multirow{8}{*}{134} & \multirow{8}{*}{89.3} & S. Typhimurium & $4(25 \%)$ \\
\hline & & & & & & S. Enteritidis & $3(18.8 \%)$ \\
\hline & & & & & & S. Kentucky & $3(18.8 \%)$ \\
\hline & & & & & & S. Paratyphi A & $2(12.5 \%)$ \\
\hline & & & & & & S. Molade & $1(6.25 \%)$ \\
\hline & & & & & & S. Heidelberg & $1(6.25 \%)$ \\
\hline & & & & & & S. Infantis & $1(6.25 \%)$ \\
\hline & & & & & & S. Apeyeme & $1(6.25 \%)$ \\
\hline \multirow{6}{*}{ Ducks } & \multirow{6}{*}{60} & \multirow{6}{*}{7} & \multirow{6}{*}{11.7} & \multirow{6}{*}{53} & \multirow{6}{*}{88.3} & S. Enteritidis & $2(28.6 \%)$ \\
\hline & & & & & & S. Typhimurium & $1(14.3 \%)$ \\
\hline & & & & & & S. Paratyphi A & $1(14.3 \%)$ \\
\hline & & & & & & S. Kentucky & $1(14.3 \%)$ \\
\hline & & & & & & S. Inganda & $1(14.3 \%)$ \\
\hline & & & & & & S. Bargny & $1(14.3 \%)$ \\
\hline \multirow{3}{*}{ Quails } & \multirow{3}{*}{30} & \multirow{3}{*}{3} & \multirow{3}{*}{10} & \multirow{3}{*}{27} & \multirow{3}{*}{90} & S. Virchow & $1(33.3 \%)$ \\
\hline & & & & & & S. Tamale & $1(33.3 \%)$ \\
\hline & & & & & & S. Typhimurium & $1(33.3 \%)$ \\
\hline \multirow{2}{*}{ Turkeys } & \multirow{2}{*}{25} & \multirow{2}{*}{2} & \multirow{2}{*}{8} & \multirow{2}{*}{23} & \multirow{2}{*}{92} & S. Wingrove & $1(50 \%)$ \\
\hline & & & & & & S. Kentucky & $1(50 \%)$ \\
\hline Total* & 265 & 28 & 10.6 & 237 & 89.4 & Total n. of isolates & 28 \\
\hline
\end{tabular}

* The percentage was calculated according to the total number of examined samples.

\section{Discussion}

The clinical signs of the examined birds were retarded growth, depression, lameness, ruffled feathers, chicks huddling together, respiratory troubles, whitish watery diarrhea and accumulation of faecal matter around the vent. The postmortem examination of both freshly dead and sacrificed birds revealed gross lesion in the form of septicemia, bronze discolouration enlarged liver with necrotic foci, splenomegaly with necrotic foci, pericarditis, enlarged heart, peritonitis, congested kidneys, inflammation of intestine and caecum and unabsorbed yolk sac in young birds. Similar signs obtained by Gast and Beard [3] Shivaprasad et al. [4] and Gast and Beard [5] and similar postmortem lesions obtained by Hoop and Posuschil [7] Shalaby 
and Abdel-Hamid [22] and Abd El-Nasser et al. [23]. The occurrenec of Salmonella species was $10.6 \%$ from different poultry species. This is nearly similar to Taha [24] who isolated salmonellae from chicken with a percentage of $10 \%$ in Egypt, and Roy et al. [25] who isolated $11.99 \%$ Salmonella spp.) from poultry and poultry products. While, higher isolation rates were reported by Osman [26] who reported the islation of Salmonella spp. (30\%) from poultry dropping from different broiler farms in Egypt. However, El-Zeedy et al. [27] reported lower isolation rate of Salmonella spp. from different poultry samples $(4.1 \%)$ in Egypt. Such variation could be attributed to differences in environmental contamination, health control programs, management systems and/or the sensitivity of the procedure used in examination.

Table 3: Distribution of some virulence genes in the examined 28 Salmonella isolates among different poultry species

\begin{tabular}{|c|c|c|c|c|c|c|}
\hline Code & Serovars & Source & sopB & bcfC & spvC & stn \\
\hline 1 & S. Kentucky & chickens & + & + & - & + \\
\hline 2 & $S$. Molade & chickens & + & + & - & + \\
\hline 3 & $S$. Typhimurium & chickens & + & + & - & + \\
\hline 4 & $S$. Kentucky & chickens & + & + & - & + \\
\hline 5 & $S$. Heidelberg & chickens & + & + & - & + \\
\hline 6 & $S$. Enteritidis & chickens & + & + & - & + \\
\hline 7 & $S$. Paratyphi A & chickens & + & + & - & + \\
\hline 8 & $S$. Typhimurium & chickens & + & + & - & + \\
\hline 9 & $S$. Typhimurium & chickens & + & + & - & + \\
\hline 10 & $S$. Infantis & chickens & + & + & _ & + \\
\hline 11 & $S$. Enteritidis & Chickens & + & + & - & + \\
\hline 12 & $S$. Typhimurium & Chickens & + & + & - & + \\
\hline 13 & $S$. Kentucky & Chickens & + & + & - & + \\
\hline 14 & $S$. Paratyphi A & Chickens & + & + & - & + \\
\hline 15 & $S$. Apeyeme & Chickens & + & + & - & + \\
\hline 16 & $S$. Enteritidis & Chickens & + & + & - & + \\
\hline 17 & $S$. Typhimurium & Ducks & + & + & - & + \\
\hline 18 & S. Paratyphi A & Ducks & + & + & - & + \\
\hline 19 & $S$. Enteritidis & Ducks & _- & + & - & + \\
\hline 20 & $S$. Kentucky & Ducks & - & + & - & + \\
\hline 21 & $S$. Inganda & Ducks & - & + & - & + \\
\hline 22 & $S$. Bargny & Ducks & - & + & $\overline{+}$ & + \\
\hline 23 & $S$. Enteritidis & Ducks & - & + & _- & + \\
\hline 24 & S. Virchow & Quails & - & + & - & + \\
\hline 25 & $S$. Tamale & Quails & - & + & $\overline{+}$ & + \\
\hline 26 & $S$. Typhimurium & Quails & - & + & + & + \\
\hline 27 & $S$. Wingrove & Turkeys & - & + & _ & + \\
\hline 28 & $S$. Kentucky & Turkeys & - & + & - & + \\
\hline Total & 28 & & $\begin{array}{l}18 \\
(64.3 \%)\end{array}$ & $\begin{array}{l}28 \\
(100 \%)\end{array}$ & $\begin{array}{l}3 \\
(10.7 \%)^{*}\end{array}$ & $\begin{array}{l}28 \\
(100 \%)\end{array}$ \\
\hline
\end{tabular}

* The percentage was calculated according to the total number of identified serovars.

The number and percentages of positive chickens, ducks, quails and turkeys were 16 (10.7\%), $7(11.7 \%), 3(10 \%)$ and $2(8 \%)$, respectively. The highest percentage of Salmonella isolation was from ducks while the lowest percentage was from turkeys. The results of salmonella isolation from chickens $(10.7 \%)$ in this study coordinated with El-Azzouny [28] who recorded a percentage of $10 \%$ in broilers and Rehan [29] who isolated
Salmonella spp. from $12 \%$ of broiler chickens. Lower percentages were previously reported by Sadoma [30] and Mohamed et al. [31] who isolated Salmonella from chicken farms in Gharbia and Kafr-Elsheikh with an overall prevalence of $2 \%$ and $2.5 \%$, respectively. However, higher percentage was recorded by Osman [26] who collected 150 random samples from different broiler farms and isolated 45 Salmonella strains with the 
percentage of $30 \%$. The variation in the percentage of Salmonella detection among poultry could be attributed to different factors including management, biosecurity, as well as, prophylactic antibiotics used in each circumstance [19].

The results of salmonella isolation from ducks $(11.7 \%)$ in this study coordinated with Abd El-Tawab et al. [32] who isolated Salmonella from ducks with the percentage of 9.6\% and Hoszowski and Wasyl [33] who detected salmonella in ducks with percentage of $14.3 \%$. Higher isolation rates were previously recorded by Osman et al. [26] who reported an isolation rate of Salmonella spp. from $18.5 \%$ of ducks. In addition, Ismail [34] reported the percentage of isolation from ducks was $27.02 \%$.
The obtained results were nearly similar to those obtained by Abd El- Tawab et al. [32] who isolated Salmonella spp. from quails with the percentage of $10 \%$, also, Palanisamy and Bamaiyi [35] reported Salmonella isolation from $11.11 \%$ of quails. However, the results were different than those reported in Iran, where, Salmonella isolation rate reached $40 \%$ as reported by Jalali et al. [36] and in Brazil reached $75 \%$ as reported by Neto et al. [37].

In the present study Salmonella spp. were isolated from turkeys with a percentage of $8 \%$. This was nearly similar to $9.7 \%$ reported by Tel et al. [38] in fecal specimens and Alatfehy [39] who reported that Salmonella isolation rate was $6.25 \%$ in turkeys.
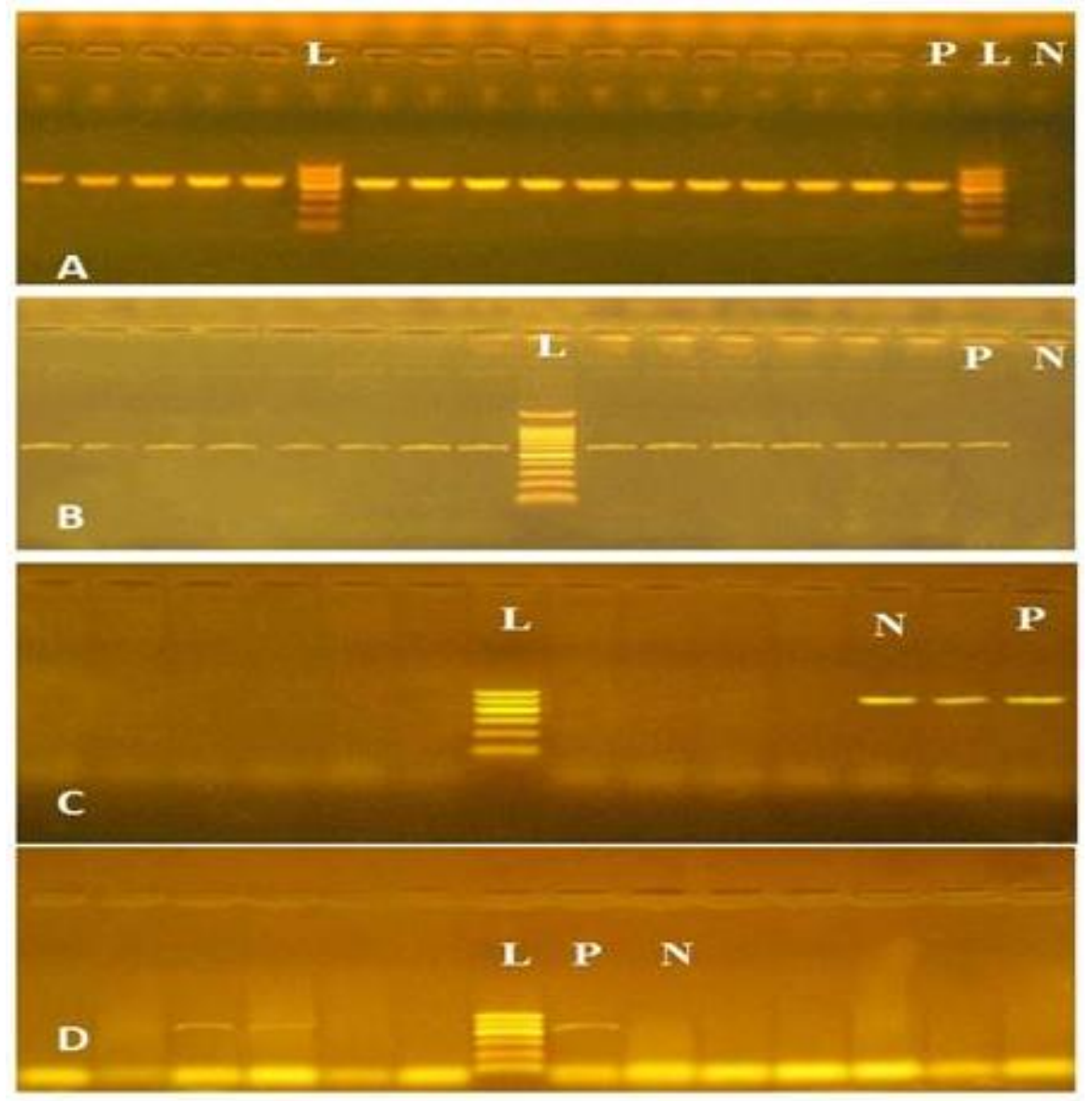

Figure 2: Agarose gel electrophoresis for amplified products of some virulence genes. A: PCR results for the bcfC gene showing positive amplification of 467 bp. B: PCR results for the stn gene showing positive amplification of $617 \mathrm{bp}$ in all samples. C: PCR results for the sopB gene showing positive amplification of 517 bp.D: PCR results for the $s p v C$ gene showing positive amplification of $467 \mathrm{bp}$. 
Salmonella isolates were serotyped using poly and monovalent "O" and" $H$ " antisera and the result of this study revealed that 16 strains were isolated from chickens from different Governorates. The results in this study revealed that $S$. Typhimurium predominated other serotypes. These results agreed with Hoszowski et al. [9] who reported that $S$. Enteritidis and $S$. Typhimurium were the most common serotypes isolated from poultry. Whereas, Dahal [40] recorded that $S$. Entertidis is the most frequently isolated serotype $(84.62 \%)$ followed by $S$. Typhimurium (15.38\%).

The results of serotyping of 7 different Salmonellae from ducks in the current study showed that $S$. Entertidis (28.6\%)and $S$. Typhimurium $(14.3 \%)$ predominated other serotypes. These results coincide with Hoszowski and Wasyl [33] who detected Salmonella in duck broilers with the percentage of $14.3 \%$ and the most frequent serovars were $S$. Entertidis, $S$. Infantis, $S$. Hadar and $S$. Typhimurium. However, ElSawy [41] isolated Salmonella spp. from ducklings in Kalioubia Governorate and they were identified as: $S$. Typhimurium, $S$. Tshiongwe, $S$. Newport, $S$. Nchanga, $S$. Tuebingen and $S$. Bovis- mobificans.

Regarding serotyping of 3 different Salmonella isolates from quails, 3 different serogroups were identified as $S$. Virchow $(33.3 \%), \quad S$. Tamale $(33.3 \%)$ and $S$. Typhimurium (33.3\%). Different Salmonella spp. were previously serotyped by Neto et al. [37] who reported $S$. Corvalis; $S$. Give; $S$. Lexington; $S$. Minnesota; $S$. Schwarzengrund; $S$. Rissen and $S$. Typhimurium from meat-type quails in Brazil.

In the present study, 2 different serogroups were identified as $S$. wingrove $(50 \%)$ and $S$. Kentucky (50\%) from turkeys. Hird et al. [42] reported that $S$. Kentucky, $S$. Anatum, $S$. Heidelberg, $S$. Reading, and $S$. Senftenberg were identified from turkeys at the California Veterinary Diagnostic Laboratory System. The variation of prevelance might be due to geographical variation, differences in management, type of samples, age of examined birds, season, poor hygienic conditions and inadequate nutrition.
Results of PCR for the detection of $b c f C$ from 28 isolated strains showed that it was present in all the isolates (100\%). Nearly similar results were obtained by Osman et al. [26] who reported $b c f C$ gene in $100 \%$ of the Salmonella serovars isolated from humans and day-old ducklings. Also, Alatfehy [39] recorded that $b c f C$ gene with the percentage of 95.7\% was identified in Salmonella isolates from poultry. However, El-Sayed [43] reported the absence of $b c f C$ gene in Salmonella strains isolated from ducklings.

The results of our study revealed that $\operatorname{sop} \mathrm{B}$ gene was detected in 18 isolates with the percentage of $64.3 \%$. Nearly similar results were obtained by Osman et al. [26] who detected sopB gene with the percentage of $54.3 \%$. However, lower percentage $(15.4 \%)$ was reported by El-Sayed [43].

In the present study, $s p v \mathrm{C}$ gene was detected in 3 isolates only with the percentage of $10.7 \%$. Similar results was obtained by ElAzzouny [28] who identified $s p v$ gene in 6\% of Salmonella isolates. The results disagreed with Amini et al. [44] who detected spv gene in $30 \%$ of Salmonella strains isolated from poultry and Moussa et al. [45] who reported that $s p v$ gene was present in $31.5 \%$ in $S$. Entertidis and $30 \%$ in $S$. Typhimurium isolated from poultry. In addition, the result of our study revealed that the stn gene was present in all of the isolates (100\%). In accordance, Murugkar et al. [21] and Shalaby [46] reported that stn gene was detected in all the isolated Salmonella strains. Moreover, Zou et al. [16] identified $\operatorname{stn}$ gene in all 425 isolates $(100 \%)$ of poultry origin.

\section{Conclusion}

In conclusion, different Salmonella species of different serotypes carrying common virulence genes were recovered from domestic birds in the examined areas of Delta, Egypt. Therefore, strictly hygienic and biosecurity measures must be applied in poultry management to avoid spread of salmonellae.

\section{Conflict of interest}

All the authors have no conflict of interest to declare. 


\section{References}

[1] Rao, V. and Chauhan, H.V. (1987): The pathology and pathogenesis of Salmonella Stanley infection in experimental chicks. Res Vet Sci, 42(3):287-293.

[2] Nagaraja, K.V.; Pomeroy, B.S. and Williams, J.E. (1991): Paratyphoid infection In Diseases of poultry, $9^{\text {th }}$ ed. B. W. Calnek, H.J. Barnes, C. W. Beard, W. M. Reid, and H. W. Yoder, Jr., eds. Iowa state university press, Ames, Iowa. PP 99130.

[3] Gast, R. K. and Beard, C. W. (1990): Production $S$. Enteritidis contaminated eggs by experimentally Infected hens. Avian Dis, 34:438-446.

[4] Shivaprasad, H. L.; Timoney, J. F.; Morales, S.; Lucio, B. and Baker, R. (1990): Pathogenesis of $S$. Enteritidis infection in laying chickens. I. Studies on egg transmission, clinical signs, fecal shedding, and serologic responses. Avian Dis: 548- 557.

[5] Gast, R. K. and Beard, C. W. (1992): Evaluation of a chick mortality model for predicting the consequences of Salmonella Enteritidis infections in laying hens. Poult Sci, 71(2): 281-287.

[6]Ibrahim, I. A. (2003): Diarrhea in duckling. M V Sc thesis, Fac. Vet. Med., Zagazig univ, Benha branch.

[7]Hoop, R. K. and Pospischill, A. (1993): Bacteriological, serological, histological and immunohistochemical findings in laying hens with naturally acquired Salmonella Entertidis phage type 4 infection. Vet Rec, 133(16): 391-393.

[8]Hendriksen, R. S. (2003): Global Salm-surv A global Salmonella surveillance and laboratory support project of the world health organization. Laboratory protocols level 1 Training Course Identification of Salmonella $4^{\text {th }}$ Ed. April 2003.

[9]Hoszowski, A.; Wasly, D. and Truszczyrski, M. (2000): Salmonella serovars determined in the National Veterinary Research Institute in 19941998. Bull Vet Instit Putawy, 44 (1): 3338.
[10]Falkow, F. (1996): The Evolution of pathogenicity in Esherichia, shigella and Salmonella In (ASM Press) Escherichia Coli and Salmonella chapter 149, P: $2723-2729$.

[11] Groisman, E. A. and Ochman, H. (1997): How Salmonella became a pathogen. Trends in Microbiology, 5(9):343-348.

[12] Huehn, S.; La Ragione, R.M.; Anjum, M.; Saunders, M.; Woodward, M.J.; Bunge, C.; Helmuth, R.; Hauser, E.; Guerra, B.; Beutlich, J.; Brisabois, A.; Peters, T.; Svensson, L.; Madajczak, G.; Litrup, E.; Imre, A.; Herrera-Leon, S.; Mevius, D.; Newell, D.G. and Malorny, B. (2010): Virulotyping and Antimicrobial Resistance Typing of Salmonella enterica Serovars Relevant to Human Health in Europe. Food Borne Pathog Dis, 7(5): 523-535.

[13] Galán, J. E. and Zhou, D. (2000): Striking a balance: modulation of the actin cytoskeleton by Salmonella. Proc Natl Acad Sci, 97(16): 8754-8761.

[14] Borges, K. A.; Furian, T. Q.; Borsoi, A.; Moraes, H. L. S.; Salle, C. T. P. and Nascimento, V. P. (2013): Detection of virulence-associated genes in Salmonella Enteritidis isolates from chicken in South of Brazil. Pesquisa Veterinária Brasileira, 33(12): 1416-1422.

[15]Swamy, S. C.; Barnhart, H. M.; Lee, M. D.; Dreesen, D. W. (1996): Virulence Determinants $i n v \mathrm{~A}$ and $s p v \mathrm{C}$ in salmonellae isolated from Poultry Products, Waste water and Human Sources. Appl Environ Microbiol, 62(10):3768-3771.

[16]Zou, M.; Keelara, S. and Thakur, S. (2012): Molecular Characterization of Salmonella enterica Serotype Enteritidis Isolates from Humans by Antimicrobial Resistance, Virulence Genes, and Pulsed-Field Gel Electrophoresis. Foodborne Pathogens and Disease, 9 (3):232-238

[17]ISO 6579 (2002): Microbiology of food and animal feeding stuffs- horizontal method for the detection of Salmonella 
SPP, International standard, $4^{\text {th }}$ Ed., pp: 7- 15.

[18]Kauffman, F. (1974): Serological diagnosis of Salmonella species. Kauffman white scheme Minkagaord, Copenhagen, Denmark.

[19] World health organization WHO (2007): Salmonella epidemiology. http://www.safe poultry.com/ Salmonella epidemiology.asp.

[20] Oliveira, S. D.; Rodenbusch, C. R.; Cé, M. C.; Rocha, S. L. and Canal, C. W. (2003): Evaluation of selective and nonselective enrichment PCR procedures for Salmonella detection. Lett Appl Microbiol, 36(4):217-221.

[21] Murugkar, H.; Rahman, H. and Dulta, P. (2003): Distribution of virulence genes in Salmonella serovars isolated from man and animals. Indian Journal of Medical Research, 117:66-70.

[22] Shalaby, N. A. and Abdel-Hamid, H. S. (1987). Microbial agents responsible for embryonic mortalities in hatcheries in Gharbia Province. Zagazig VetJ, 5(2): 165-175.

[23] Abd El-Nasser, A.; Mahmoud, F. M.; ElShabiny, L. M.; Hassanein, Z. A. and Abbas, A. A. (1994): Studies on major bacterial agents causing arthritis in chickens in Qalyoubia province. Veterinary Medical Journal Giza, 42(1 B):277-285.

[24]Taha, N. A. A. (2002): Zoonotic importance of entero pathogenic $E$. coli (EPEC). Ph.D. Thesis, Fac. Vet. Med. Zagazig Univ.

[25] Roy, P.; Dhillon, A. S.; Lauerman, L. H.; Schaberg, D. M.; Bandli, D. and Johnson, S. (2002): Results of Salmonella isolation from poultry products, environment, and other characteristics. Avian Dis, -46(1):17-24.

[26] Osman, M.M. (1992): Studies on bacterial causes of early poultry mortality in Sharkia Governorate. M.V.Sc., Thesis, Fac. Vet. Med., Zagazig Univ.

[27] El-Zeedy, S. A.; Eldeen, H. K. and Badr, G. M.(2007): Protein analysis for comparison between salmonellae isolated from different poultry species. BSVet Med J, 17(2):1-9.

[28]El-Azzouny, M. M. E. (2014): Occurrence of virulence genes among multidrug resistant Salmonellae isolated from broilers. Ph.D. Thesis, Fac. Vet. Med. Zagazig Univ.

[29] Rehan, H.M.A. (2004): Application of PCR identification of Salmonella in chickens. M.V.Sc., Thesis, Fac. Vet. Med., Mansoura Univ.

[30] Sadoma, A. M. (1997): Salmonella in chicken in connection with human infection. M.V.Sc. Thesis, Fac. Vet. Med., Tanta Univ.

[31] Mohamed, L.N.; Samaha, H.A.; Draz, A.A. and Haggage, Y.N. (1999): Salmonellae among birds and human beings. Alex J Vet Sci, 15 (1): 147-154.

[32] Abd El-Tawab, A. A.; Ammar, A. M.; Soad, A. N., El- Hofya, F. I. and Nabil, N. M. (2015): Studies on different Salmonella serotypes isolated from poultry in different governorates in Egypt. Benha VetMed J, 28 (2):169-175.

[33] Hoszowski, A. and Wasyl, D. (2005): Salmonella prevalence and resistance to antibiotics in Poland. Medycyna Weterynaryjna, 61(6): 660-663.

[34]Ismail, R. H. I. (2013): Some studies on bacterial causes of respiratory troubles in ducklings. M. V. Sc. Thesis, Fac. Vet. Med., Zagazig Univ.

[35]Palanisamy S. and Bamaiyi P. H.(2015): Isolation and Antibiogram of Salmonella spp. from Quails in a Farm from Kelantan, Malaysia. J Vet Adv, 5(12): 1191-1198.

[36]Jalali, M.; Abedi, D.; Pourbakhsh, S. A. and Ghokasin, K. (2008): Prevalence of Salmonella species in raw and cooked foods in Isfahan, Iran. J of Foods Safety, 28 (3): 442-452.

[37]Neto, F.; Angela, H.L.; Guastalli, S.; Almeida, A.M. and Junior, B. (2013): Salmonella spp. in Meat-type Quails (Coturnix coturnix coturnix) in the State 
of São Paulo, Brazil. Brazilian $\mathbf{J}$ of Poultry Science, 15(3): 277-281.

[38]Tel, O. Y.; Bozkaya, F. and Keskin, O. (2013): Salmonella, Campylobacter, and Chlamydophila in bald ibis (Geronticus eremita) feces in Turkey. J Zoo Wildl Med, 44(1):21-26.

[39] Alatfehy, N. M. M. M. (2012): Genomic comparison and characterization of Salmonella enterica serovars by the use of different molecular techniques. Ph.D. Thesis, Fac. Vet. Med., Cairo Univ.

[40] Dahal, N.; Ellerbroek, L. and Poosaran, N. (2007): Prevalence and Antimicrobial Resistance of Salmonella in Imported Chicken Carcasses in Bhutan. National Cent Anim Health, 1:1-92

[41] El-Sawy, E. (1976): Studies on Salmonellosis in ducks. M. V. Sc. Thesis, Fac. Vet. Med., Cairo Univ.

[42] Hird, D. W.; Kinde, H.; Case, J. T.; Charlton, B. R.; Chin, R. P. and Walker, R.L. (1993): Serotypes of Salmonella isolated from California turkey flocks and their environment in 1984-89 and comparison with human isolates. Avian Dis, 37(3):715-719.

[43] El-Sayed, Z. A. E. (2014): Bacteriological Studies on Salmonella isolated form imported One-day old Ducklings. M. V. Sc. Thesis, Fac. Vet. Med., Cairo Univ.

[44] Amini, K.; Salehi, T.Z.; Nikbakht, G.; Ranjbar, R.; Amini, J. and Ashrafganjooe, S.B. (2010): Molecular detection of invA and spv virulence genes in Salmonella Enteritidis isolated from human and animals in Iran. AfrJ Microbiol Res, 4 (21): 2202-2210.

[45] Moussa, I. M.; Aleslamboly, Y. S.; AlArfaj, A. A.; Hessain, A. M.; Gouda, A. S. and Kamal, R. M. (2013): Molecular characterization of Salmonella virulence genes isolated from different sources relevant to human health. J Food Agriculture and Environment,11(2):197201.

[46] Shalaby, A. G. A. (2012): Further studies on Salmonella species isolated from wild birds. Ph.D. Thesis, Fac. Vet. Med., Cairo University. 


$$
\begin{aligned}
& \text { الملخص العربى } \\
& \text { التوصيف المظهري والوراثي للسالمونيلا باراتيفويد المعزولة من الدواجن في منطقة الدلتاـ مصر }
\end{aligned}
$$

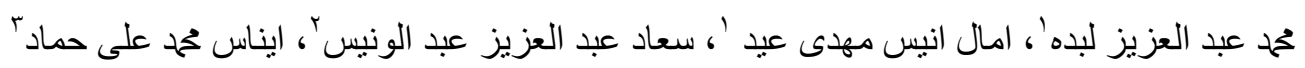

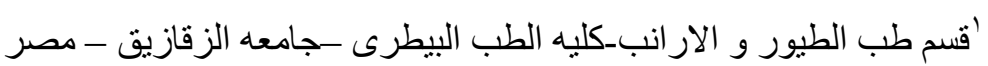

$$
\begin{aligned}
& \text { זالمعمل المرجعى للرقابه البيطريه على الانتاج الداجنى- معهد بحوث صحه الحيو ان - الدقىـ الجيزة- مصر }
\end{aligned}
$$

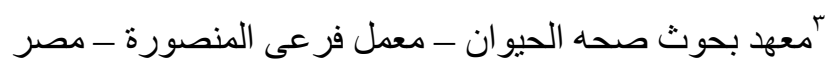

تهدف هذه الدراسة الي وتصنيف ميكروب سالمونيلا بار اتيفويد من الدجاج ,البط ,السمان و الرومى من خمسه محافظات

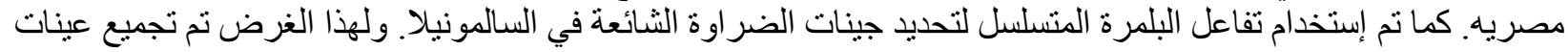

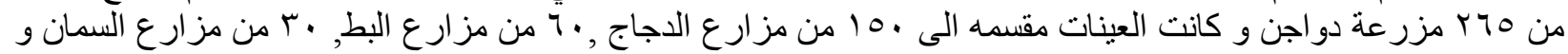

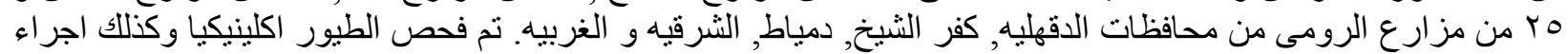

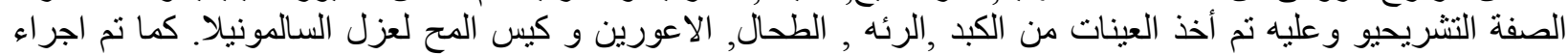

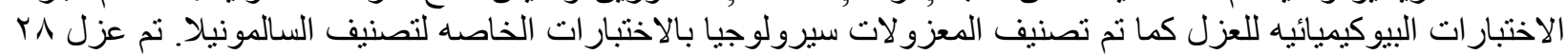

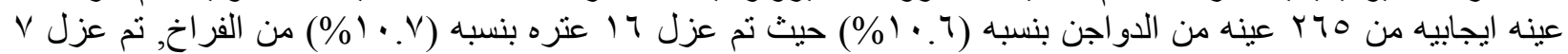

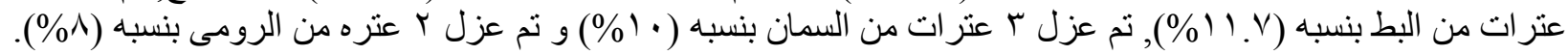

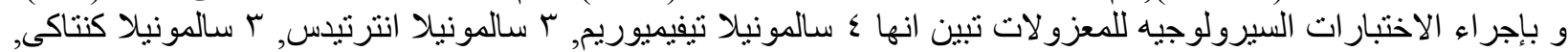

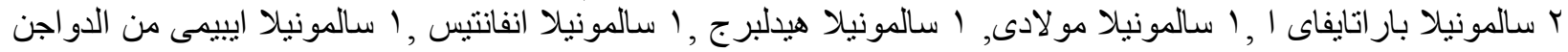
بنسبه (\% عزل r سالمونيلا انترنيدس , l عنره سالمونيلا من كل من سالمونيلا تيفيميوريج, سالمونيلا بار اتايفاى ا, سالمونيلا كنتاكى,

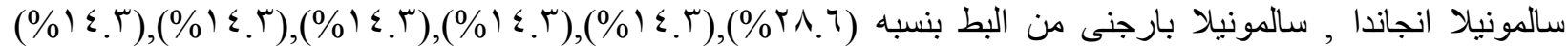

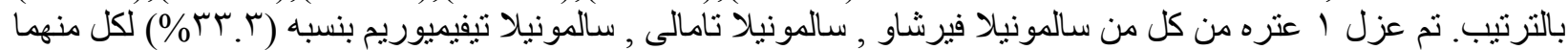

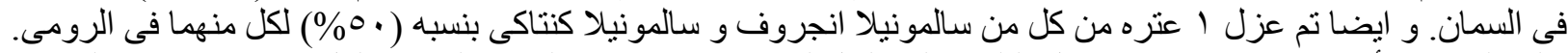

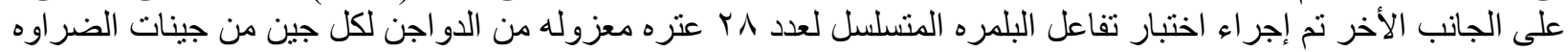

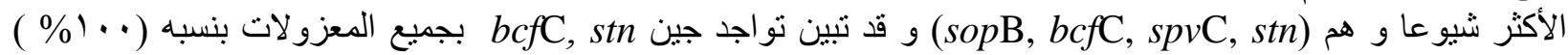
يليهما

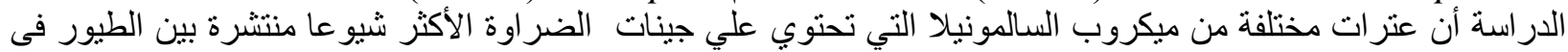

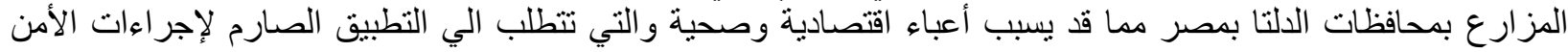
الحيوي في مزارع الدواجن. 